\title{
Refusal Strategies Used By Multi-Nationality Students
}

\author{
I.A.R. Dewi ${ }^{1}$, D.K. Tantra ${ }^{2}$, L.P. Artini ${ }^{3}$, N.M. Ratminingsih ${ }^{4}$ \\ ${ }^{1234}$ English Language Education, Post Graduate Program, Universitas Pendidikan Ganesha, Singaraja \\ e-mail: ratsithadewi93@gmail.com, komang.tantra@undiksha.ac.id, putu.artini@undiksha.ac.id, \\ made.ratminingsih@undiksha.ac.id
}

\begin{abstract}
This descriptive qualitative study was aimed at exploring refusal strategies used by the students of primary level of Gandhi Memorial Intercontinental School (GMIS) Bali in requesting, offering, inviting, and suggesting. The students being involved as the subject of this study were multi nationality (Indonesian, Indian, Russian, and Japanese) male and female students of the third, fourth and fifth grade which were determined using purposive sampling technique. Data collection was conducted through observation, recording, and note taking employing video recorder, camera, and field note as the instruments of the data collection. Data analysis in this study was done through four concurrent activities covering data collection, data reduction, data display, and conclusion. The result shows that, in context of request across nationalities, view from the frequency (percentage of refusals) it shows direct refusal is highly used by Russian while it is the lowest by Indonesian students. On the contrary indirect strategy is more often used by Indonesian students. It reflects that Indonesian is mostly to refuse it in direct way but this is contrast with Russian who perform direct refusal in less frequent. This condition is in context of refusing in indirect way. the data reveal that Russian are more often to refuse the offering in indirect way while Indonesian is the lowest. In context of refusing invitation, nationality which is the highest used of direct refusal is Indian while nationality which was prefer to perform indirect refusal is Russian. In addition, in context of Suggestion, direct refusal is highly performed by Russian whereas indirect refusal is more often used by Japanese students.
\end{abstract}

Keywords: refusal strategies, multi-nationality, inter-cultural communication, primary level

\section{Introduction}

Communication plays a vital role in human life. It allows humans to share ideas, express feeling or convey any message to others. During the process of communication, they do not merely accept other people's ideas, desires, opinions, and comments, but also sometimes need to refuse them when they are contradicted with the interlocutors'. Refusal is an unpleasant response which commonly occurs in daily communication since people have their own ideas or beliefs which make them impossible to always accept other's. Signs of refusal can be shown through verbal or non-verbal reaction. Verbally, refusals are expressed through speech utterance, however nonverbal refusals are simply expressed through facial expression or body motion like silent, shaking head etc. (Cheng et al. quoted in Hedayatnejad \& Maleki, 2016).

Refusal in English occurs to both native speakers and non-native speaker of English when they are involved in a communication. Communication which involves native and nonnative English speaker is known as intercultural communication. Spencer-Oatey (2006) points out that intercultural communication is concerned with communication between people from different sociocultural. As a means of intercultural or international communication, performing refusal in English becomes crucial since refusing in an inappropriate way carries risk of offending other negative, as consequence it may breakdown the communication. Moreover, according to Shboul and Huwari (2016), people communicate not only to convey information and express feeling, ideas, but also more importantly maintain relationship.

The refusal is generally executed in context of request, invitations, offers, and suggestion. In line with this, Gass and Houck (1999: 28) point out that this occurs as a negative response to other acts such as requests, invitations, offers, and suggestions (Illiadi \& Larina, 2017). The skill of refusing another's offer, request, or invitation, without hurting his or her feeling is very important since the "inability to say no clearly has led many non-native speakers offend their interlocutors (Ramos, cited in Al Kahtani, 2005). On its realization, 
refusals are generally performed in two different ways, direct and indirect. A refusal is considered as a direct refusal if the meaning of utterance can be understood as refusal. Meanwhile, when an utterance implicitly contains ambiguous meaning it belongs to indirect refusal.

Even though refusal exists in all languages, not all language culture refuses in the same way. Refusal like any other speech acts, is believed to be universal and culturally distinctive (Chojimah, 2015). Sattar, et al. (2013) Sattar, A. Hibba. Q. A., Salasiah C. \& Suleiman, Raja Rosina, Wijayanto (2013), Morkus (2009), and Nadar et al. (2005) also suggest that speech act of refusal is indeed culturally distinctive. It implies that the use of refusals is governed by cultural norms. Numbers of studies involved native speakers of Arabics such as Saudi Arabia (Al-Kahtani, 2005), Yemenis (Al-Eryani, 2007), Egyptians (Nelson, 2002) and Jordanian (Al-Issa, 2003). These studies found differences in the ways people from different cultural backgrounds perform refusal even while using the same linguistic code (English) (Sattar, et al. 2011). It reflects cultural norms of L1 affect the way a person refuses in another language.

Since different background culture of people refuse differently, it can be assumed that they have different ideas about how to do a refusal. Al-Issa (2003) asserts that the cultural background of people may affect the way they interact, interpret and apprehend (Han \& Tazegul, 2016). A refusal can be accepted or appropriate for a certain nationality or culture, but not for other nationalities or cultures. Refusals require not only long sequences of negotiation and cooperative achievements, but also "face-saving maneuvers to accommodate the noncompliant nature of the act" (Gass and Houck, 1999 in Farnia \& Wu, 2012). Therefore, people commonly negotiate the refusal through any supportive statement which is possible to lessen the offensive or threats and possible to maintain other' negative face. Furthermore, refusal is commonly followed by statements which is functioned as a strategy to mitigate the refusal and commonly used for politeness. According to Brown and Levinson, politeness involves showing an awareness of other people's face wants (Xiaoning, 2017). Hence, the present of politeness in refusal utterance is aimed to lessen face losing or maintain other's face.

Besides socio cultural background, the utilization of refusal strategies seems to be also governed by some other aspects, such as gender, age, educational background, linguistic knowledge, and language proficiency. Felix-Brasdefer (cited in Han \& Tazegul, 2016) clarifies that social status, power, age, gender and educational level of the interlocutors may affect different use of refusal strategies.

Concerning the definition of refusal strategies, many theorists have defined term "strategy" variously. According to Kasper (1996), strategy is a term often used in pragmatics, communication theory and studies on second language acquisition, referring to interactional participants' solution to multiple conflicting goals (as cited in Li \& Sun, 2015). While Miles (1994) argues that strategy is a set of measures the communicator utilizes for the sake of smooth communication or adaptation to the social norms in which he lives (Li \& Sun, 2015). In other words, strategy refers to ways which facilitate communicator to create effective and successful communication. Thus, refusal strategies can be defined as various ways to express refusal or to contradict interlocutor's expectation.

This study follows the theory of refusal strategies proposed by Beebe, Takahashi, and Uliss-Weltz (1990), in which their classification has become the mostly used refusals taxonomy. They categorize the strategies according to refusals to requests, invitations, suggestions, and offers. Their taxonomy includes direct, indirect, and adjunct strategies. Direct refusal strategy deals with the way to refuse in a straight forward way to the interlocutor. Some examples of direct strategies expressions are no, I can't, can't be done/ allowed, don't, forget it, I refuse, and I object. Those kinds of expressions are denied vocabularies or statements that show reluctance or inability (Beebe et al., 1990). For the present study, the continuum of directness consists of two sub strategies, namely performative and non-performative statement. The second taxonomy is indirect refusal strategy. This strategy mainly concerns with the ways to express refusal implicitly. Indirectness takes place when there is a difference between the expressed meaning and the 
implied meaning (Thomas, 1995 in Mulyani, 2013). As proposed by Beebe et al (1990, p.73), the indirectness strategies consists of 11 sub strategies, namely (1) statement of apology/ regret, (2) wish, (3) excuse/ reason/ explanation, (4) statement of alternative, (5) set condition for future or past acceptance, (6) promise of future acceptance, (7) statement of principle, (8) statement of philosophy, (9) attempt to dissuade the interlocutor, (10) acceptance that functions as a refusal, (11) avoidance. Then the third taxonomy is adjunct refusal strategy. It is something to do with additional information which either maximize or minimize the refusal. As indicated by Sadeghi and Savojbolaghchilar (2011), adjuncts are the third category of refusals used by interlocutors. Adjuncts are expressions that are associated with refusals, but do not convey refusals alone. They have the following subcategories: adjuncts refer to those expressions that accompany a refusal but do not constitute a refusal by themselves. These include statement of positive opinions/ feeling or agreement, statement of empathy, pause fillers, and gratitude/ appreciation

Beside of the fact that refusal strategies matter mainly for building and maintaining intercultural communication and relationship as stated previously, choosing refusal as the main topic of this research is due to there are few studies examining refusal strategies. According to Athieh and Yassin (2011), there have been a lot of studies on the speech acts of request, compliment, apology and complaint in the sociocultural pragmatics, but not on refusal. Refusals have not much studied but are being paid increasing attention to (Beebe, et.al.,1990; Bardovi-Hartford, 1990; Liao and Breshnahan, 1996; Blum-Kulka and Olshtain 1984; Gass 1999; Takahashi and Beebe 1987; Nelson and Cason 2002 in Farnia \& Wu, 2012). Moreover, from those researches which examine refusal strategies, it is found that only few researches which investigate the use of refusal strategies by non-native speaker of English. Out of fifteen studies in the topic of refusals, only six included non-native speakers of English and only four of these studies examined how non-native speakers of languages other than English utilized English in making refusals (Beebe, et.al., 1990; Chen, 1995; King and Silver,1993 in Farnia \& Wu, 2012). Thus, the researcher initiates to investigate the use refusal strategies by non-native speakers of English in Gandhi Memorial Intercontinental School Bali (GMIS).

\section{Method}

This research used a descriptive qualitative method in the form of a case study as its design. It involved the primary level students of Gandhi Memorial Intercontinental School (GMIS) as the subjects of the study, which were determined using purposive sampling technique. Meanwhile, the object of this study was refusal strategies used in English by those multi-nationality students (Indonesian, Japanese, Indian, and Russian). The data collection was done through obervation, recording, interview, and note taking. The observation was focused on the students when they interacted one another among different nationalities, Indonesian, Japanese, Russian, and Indian. Recording was aimed to record the conversation among the subjects of the study, which was done at the same time of the observation to record all the activities when they were conversing. Then, note taking was done to ascertain information about student's name, gender, and nationalities. Hence, the research instruments used by the reseracher in collecting the data were video recorder, camera, and field note. The data analysis in this study was done in four concurrent activities, namely data collection, data reduction, data display, and conclusion. In data collection, the researcher recorded the students when they were communcating through pair work. Then, the collected data were sorted by eleminating the data which were not appropriate with the need of the research in data reduction. Meanwhile, in data display, the sorted data were analyzed and interpreted. Finally, the analyzed data were presented in the form of result and conclusion.

\section{Results and Discussion}

Refusal speeches obtained through conversation among different nationalities, Indonesian, Japanese, Indian, and Russian conversers on four different speech acts of request, offer, invitation, and suggestion. The number of subjects involved in this research 
were 60 students consisted of 18 Indonesian students, 18 Japanese students, 12 Indian students, and 12 Russian students. The refusal speeches produced by those multinationality students were varied. The data on refusal speeches obtained were further coded based on classification of refusal strategy modified by Beebe et al. (1990) and the result of analysis is presented below on table 1 in the form of its frequency and percentage.

Table 1. Refusal Strategy Used by Multi-Nationality Students (Frequency and Percentage)

\begin{tabular}{ccrrrr}
\hline \multirow{2}{*}{ Speeches act } & Type of & \multicolumn{4}{c}{ Nationality } \\
\cline { 3 - 6 } & refusals & \multicolumn{1}{c}{ Indonesian } & \multicolumn{1}{c}{ Japanese } & \multicolumn{1}{c}{ Indian } & \multicolumn{1}{c}{ Russian } \\
\hline \multirow{3}{*}{ Request } & Direct & $6(17.14 \%)$ & $7(18.91 \%)$ & $7(36.84 \%)$ & $12(50.00 \%)$ \\
& Indirect & $28(80 \%)$ & $30(81.08 \%)$ & $12(63.15 \%)$ & $12(50.00 \%)$ \\
& Adjunct & $1(2.85 \%)$ & $0.00 \%$ & $0.00 \%$ & $0.00 \%$ \\
\multirow{5}{*}{ Offer } & Direct & $11(31.42 \%)$ & $11(28.94 \%)$ & $6(31.57 \%)$ & $5(20.83 \%)$ \\
& Indirect & $12(34.28 \%)$ & $16(42.10 \%)$ & $8(42.10 \%)$ & $12(50.00 \%)$ \\
& Adjunct & $12(34.28 \%)$ & $11(28.94 \%)$ & $5(26.31 \%)$ & $7(29.16 \%)$ \\
\multirow{3}{*}{ Invitation } & Direct & $4(15.38 \%)$ & $7(25.92 \%)$ & $6(31.57 \%)$ & $6(26.08 \%)$ \\
& Indirect & $20(76.92 \%)$ & $19(70.37 \%)$ & $12(63.15 \%)$ & $17(73.91 \%)$ \\
& Adjunct & $2(7.69 \%)$ & $1(3.70 \%)$ & $1(5.26 \%)$ & $0.00 \%$ \\
\multirow{3}{*}{ Suggestion } & Direct & $3(13.63 \%)$ & $2(6.06 \%)$ & $6(30.00 \%)$ & $9(45.00 \%)$ \\
& Indirect & $18(81.81 \%)$ & $29(87.87 \%)$ & $14(70.00 \%)$ & $11(55.00 \%)$ \\
& Adjunct & $1(4.54 \%)$ & $2(6.06 \%)$ & $0.00 \%$ & $0.00 \%$ \\
\hline
\end{tabular}

Table 1 portrays refusal strategies used by Indonesian, Japanese, Indian and Russian in responding request, offer, invitation, and suggestion. The use of refusal strategy is presented in terms of frequency (percentage) of its appearance in each context of communication. The data displayed on the table above were interpreted based on respective data of Indonesian, Japanese, Indian, and Russian request, offer, invitation, and suggestion. In context of request across nationalities, viewed from the frequency (percentage of refusals) it shows direct refusal is highly used by Russian while it is lowest used by Indonesian students. On the contrary, indirect strategy is more often used by Japanese students. While in context of refusing an offer, it reflects that Indonesian is mostly to refuse it in direct way which is in contrast with Russian who performs direct refusal in less frequent. In context of refusing in indirect way, the data revealed that Russian is more often to refuse the offering in indirect way while Indonesian is the lowest. In context of refusing invitation, nationality which is the highest user of direct refusal is Indian while nationality which prefers to perform indirect refusal is Indonesian. In addition, in context of suggestion, direct refusal is highly performed by Russian whereas indirect refusal is more often used by Japanese students.

Furthermore, the data are also presented in a specific way in terms of types of refusal strategy used by multi-nationality students in GMIS. The following table shows request refusal strategy used by multi-nationality students in GMIS. 
Table 2. Request Refusal Strategy Used by Multi-Nationality Students

\begin{tabular}{|c|c|c|c|c|}
\hline \multirow{2}{*}{ Type } & \multicolumn{4}{|c|}{ Nationality } \\
\hline & Indonesian & Japanese & Indian & Russian \\
\hline Direct & $\begin{array}{l}\text { A) Non-Performative } \\
\text { statement (6) } \\
\text { 1) "No" } \\
\text { 2) Negative } \\
\text { Willingness/ ability }\end{array}$ & $\begin{array}{l}\text { A) Non-Performative } \\
\text { statement (7) } \\
\text { 1) "No" } \\
\text { 2) Negative } \\
\text { Willingness/ ability }\end{array}$ & $\begin{array}{l}\text { A) Non-Performative } \\
\text { statement (7) } \\
\text { 1) "No" } \\
\text { 2) Negative } \\
\text { Willingness/ ability }\end{array}$ & $\begin{array}{l}\text { A) Non-Performative } \\
\text { statement (12) } \\
\text { 1) "No" } \\
\text { 2) Negative } \\
\text { Willingness/ ability }\end{array}$ \\
\hline Indirect & $\begin{array}{l}\text { A) Statement of regret } \\
\text { (2) } \\
\text { B) Excuse, reason, } \\
\text { explanation (18) } \\
\text { C) Statement of } \\
\text { Alternative (6) } \\
\text { 1) I can do X } \\
\text { instead of Y } \\
\text { 2) Why don't you do } \\
\text { X instead of Y } \\
\text { D) Attempt to dissuade } \\
\text { interlocutor } \\
\text { (Criticize the } \\
\text { request/requester, etc } \\
\text { (statement of negative } \\
\text { feeling or opinion); } \\
\text { insult /attack) (2) } \\
\text { E). Avoidance } \\
\text { 1. Nonverbal } \\
\text { a. Silence } \\
\text { b. Hesitation } \\
\text { c. Do nothing } \\
\text { d. Physical } \\
\text { departure } \\
\text { 2. Verbal } \\
\text { a. Topic Switch } \\
\text { b. Joke } \\
\text { c. repetition of part } \\
\text { of request, etc } \\
\text { d. Postponement } \\
\text { e. Hedging } \\
\end{array}$ & $\begin{array}{l}\text { A) Statement of } \\
\text { regret (4) } \\
\text { B) Excuse, reason, } \\
\text { explanation (15) } \\
\text { C) Statement of } \\
\text { Alternative (8) } \\
\text { 1) I can o X } \\
\text { instead of Y } \\
\text { 2) Why don't you } \\
\text { do X instead of Y } \\
\text { D) Set condition for } \\
\text { future or past } \\
\text { acceptance (1) } \\
\text { E) Promise of future } \\
\text { acceptance (1) } \\
\text { F) Attempt to } \\
\text { dissuade interlocutor } \\
\text { (Criticize the } \\
\text { request/requester, etc } \\
\text { (statement of } \\
\text { negative feeling or } \\
\text { opinion); insult } \\
\text { /attack) (1) }\end{array}$ & $\begin{array}{l}\text { A) Statement of } \\
\text { regret (1) } \\
\text { B) Excuse, reason, } \\
\text { explanation (5) } \\
\text { C) Statement of } \\
\text { Alternative (4) } \\
\text { 1) I can do X } \\
\text { instead of Y } \\
\text { 2) Why don't you } \\
\text { do X instead of Y } \\
\text { D) Attempt to } \\
\text { dissuade interlocutor } \\
\text { (Criticize the } \\
\text { request/requester, } \\
\text { etc (statement of } \\
\text { negative feeling or } \\
\text { opinion); insult } \\
\text { /attack) (2) }\end{array}$ & $\begin{array}{l}\text { A) Statement of regret } \\
\text { (3) } \\
\text { B) Excuse, reason, } \\
\text { explanation (9) }\end{array}$ \\
\hline $\begin{array}{l}\text { Adjuncts } \\
\text { to } \\
\text { refusals }\end{array}$ & 1. Pause filler (1) & & & \\
\hline
\end{tabular}

Table 2 presents the kinds of request refusal strategy used by multi-nationality students in GMIS. Data obtained from Indonesian students were 35 refusals which consisted of direct, indirect and adjunct refusal strategy. Among 35 refusal speeches, 6 refusal speeches are categorized into non-performative statements which contained the word 'no' and negative ability 'can't'. Further, the other 28 refusal speeches are categorized as indirect refusal speech containing 2 statement of regret, 18 refusal speeches contained excuse, reason and explanation, 6 speeches contained statement of alternative, 2 speeches are categorized into attempt to dissuade interlocutor especially threat or statement of negative consequences to the requester as well as postponement. The next one is from Japanese students, 7 direct refusal strategies, whereas among 30 indirect refusal speeches, it was found 4 statements of regret, 15 statements of excuse, explanation, and reason, 8 statements of alternative, 1 condition for future or past acceptance, 1 promise of future acceptance, and 1 attempt to dissuade: criticize for the request. In performing direct refusal, the Indian students preferred to use non-performative statement rather than the performative ones. On its realization the non-performative refusal statement was performed through 7 speeches or statements covered the word 'no' and through statement which expressed unwillingness. Moreover, the data also revealedd that there are 12 refusal speeches which 
were classified as indirect refusal by which they were varied in terms of strategies used. From 12 refusal speeches, 1 statement of regret, 5 excuse/reason/explanation, 4 statements of alternative, and 2 attemot to dissuade interlocutor. The last one is the request refusal speeches performed by Russian students in communication. Refusal speeches obtained from communication involved Russian as refuser were 24 speeches in total. With respect to the refusal strategy taxonomy, those 24 refusal speeches were categorized as direct and indirect refusal types, none of them was categorized as adjunct to refusal. Among 24 refusal speeches, 12 of them were classified as direct refusal type, whereas the others were categorized as indirect refusal. Furthermore, 12 indirect refusal speeches were classified into different indirect refusal strategies, 3 of them were classified as using statement of regret strategy since it contained apologize word like "sorry". Then, 9 of them were included in reason, excuse and explanation strategy.

Table 3. Offers Refusal Strategy Used by Multi-Nationality Students

\begin{tabular}{|c|c|c|c|c|}
\hline \multirow{2}{*}{ Type } & \multicolumn{4}{|c|}{ Nationality } \\
\hline & Indonesian & Japanese & Indian & Russian \\
\hline Direct & $\begin{array}{l}\text { A) Non-Performative } \\
\text { statement (11) } \\
\text { 1) "No" } \\
\text { 2) Negative } \\
\text { Willingness/ ability }\end{array}$ & $\begin{array}{l}\text { A) Non-Performative } \\
\text { statement (11) } \\
\text { 1) "No" } \\
\text { 2) Negative } \\
\text { Willingness/ ability }\end{array}$ & $\begin{array}{l}\text { A) Non-Performative } \\
\text { statement (6) } \\
\text { 1) "No" } \\
\text { 2) Negative } \\
\text { Willingness/ ability }\end{array}$ & $\begin{array}{l}\text { A) Non-Performative } \\
\text { statement (5) } \\
\text { 1) "No" } \\
\text { 2) Negative } \\
\text { Willingness/ ability }\end{array}$ \\
\hline Indirect & $\begin{array}{l}\text { A) Statement of regret } \\
\text { (1) } \\
\text { B) Excuse, reason, } \\
\text { explanation ( } 7 \text { ) } \\
\text { C) Statement of } \\
\text { Alternative (1) } \\
\text { 1) I can o X instead } \\
\text { of } Y \\
\text { 2) Why don't you } \\
\text { do X instead of } Y \\
\text { D) Attempt to dissuade } \\
\text { interlocutor (Self- } \\
\text { defense) (3) }\end{array}$ & $\begin{array}{l}\text { A) Statement of regret } \\
\text { (1) } \\
\text { B) Excuse, reason, } \\
\text { explanation (12) } \\
\text { C) Promise of future } \\
\text { acceptance (1) } \\
\text { D) Attempt to dissuade } \\
\text { interlocutor (Self- } \\
\text { defense) (3) }\end{array}$ & $\begin{array}{l}\text { A) Excuse, reason, } \\
\text { explanation (6) } \\
\text { B) Attempt to dissuade } \\
\text { interlocutor (Self- } \\
\text { defense) (2) }\end{array}$ & $\begin{array}{l}\text { A) Excuse, reason, } \\
\text { explanation (10) } \\
\text { B) Statement of } \\
\text { Alternative (1) } \\
\text { 1) I can do X } \\
\text { instead of Y } \\
\text { 2) Why don't you } \\
\text { do X instead of Y } \\
\text { C). Avoidance (1) } \\
\text { 1. Nonverbal } \\
\text { a. Silence } \\
\text { b. Hesitation } \\
\text { c. Do nothing } \\
\text { d. Physical } \\
\text { departure } \\
\text { 2. Verbal } \\
\text { a. Topic Switch } \\
\text { b. Joke } \\
\text { c. repetition of } \\
\text { part of request, etc } \\
\text { d. Postponement } \\
\text { e. Hedging } \\
\end{array}$ \\
\hline $\begin{array}{l}\text { Adjuncts } \\
\text { to } \\
\text { refusals }\end{array}$ & $\begin{array}{l}\text { 1. Pause filler (1) } \\
\text { 2. Gratitude/ } \\
\text { appreciation (11) }\end{array}$ & $\begin{array}{l}\text { 1. Gratitude/ } \\
\text { appreciation (11) }\end{array}$ & $\begin{array}{l}\text { 1. Gratitude/ } \\
\text { appreciation (5) }\end{array}$ & $\begin{array}{l}\text { 1. Gratitude/ } \\
\text { appreciation (7) }\end{array}$ \\
\hline
\end{tabular}

Table 3 reveals the classification of offers refusal speeches performed by multinationality students in communication. Refusal speeches obtained from communication involved offering speech act of Indonesian students were 35 speeches. Among those 35 refusal speeches, 11 of them were classified as direct, 12 speeches were indirect, and 12 were adjuncts to refusals. Among 11 direct refusal speeches, all were categorized as nonperformative statements. There were varied strategies of indirect refusal, 12 speeches of indirect included in some strategies: 1 was a statement of regret, 7 of them were classified as excuse, reason, and explanation strategies, 1 was statement of alternative, and 3 of them were attempt to dissuade interlocutor, especially the statement about defensing self from other intervention. Among12 refusal speeches categorized as adjunct to refusals, 1 of them was pause filler while 11 of them were categorized as gratitude. The expression of gratitude like thanking was performed as additional expression which might affect the effect of refusal. 
Meanwhile, refusal speeches obtained from communication involved speeches act of offering of Japanese students were 38 speeches. Among those 38 refusal speeches, 11 of them were classified as direct, 16 speeches were indirect and 11 were adjuncts to refusals. As shown on the table 3 above, among 11 direct refusal speeches, all were categorized as non-performative statement. There were various strategies of indirect refusal, covering 16 speeches of indirect which were classified into some strategies: 1 of refusal speech was included as statement of regret and 1 was included as promise future acceptance, 12 of them were classified as excuse, reason, and explanation strategies, 3 refusal speeches were included as attempt to dissuade interlocutor, especially the statement about defensing self from other intervention. Some others indirect strategies such as wish, set condition for future or past acceptance, statement of alternative, statement of principle, statement of philosophy, attempt to dissuade interlocutor, avoidance verbal and non-verbal were not found in their communication. Concerning the adjunct to refusals, one appeared in Japanese's conversation was gratitude/appreciation (11 refusal speeches) which were generally performed as additional expression to express thankful.Then for the Indian students, refusal speeches obtained from communication involved speeches act of offering were 19 speeches. Among of those 19 refusal speeches, 6 of them were classified as direct (non-performative), 8 speeches were indirect, and 5 were adjuncts to refusals. There were various strategies of indirect refusal, covering 8 speeches: 2 speeches were attempt to dissuade interlocutor especially self-defense and 6 of them were classified as excuse, reason, and explanation strategies. For the adjunct to refusals, one appeared in Indian's conversation was only gratitude/appreciation (5 refusal speeches) that was generally performed as additional expression to express thankful.The last one coming from the Russian students in communication in context of offering, there were 24 speeches. Among those 24 refusal speeches, 5 of them were classified as direct, 12 speeches were indirect, and 7 speeches were adjunct to refusals. Among 12 indirect speeches, 10 refusal speeches were classified into excuse, reason, and explanation, 1 speech was classified as statement of alternative and 1 avoidance: verbal (repetition of part request as well). Concerning the adjunct to refusals, there was only one strategy appeared in Indian's conversation namely statement of empathy and gratitude/appreciation: 7 speeches were gratitude /appreciation.

Table 4. Invitation Refusal Strategy Used by Multi-Nationality Students

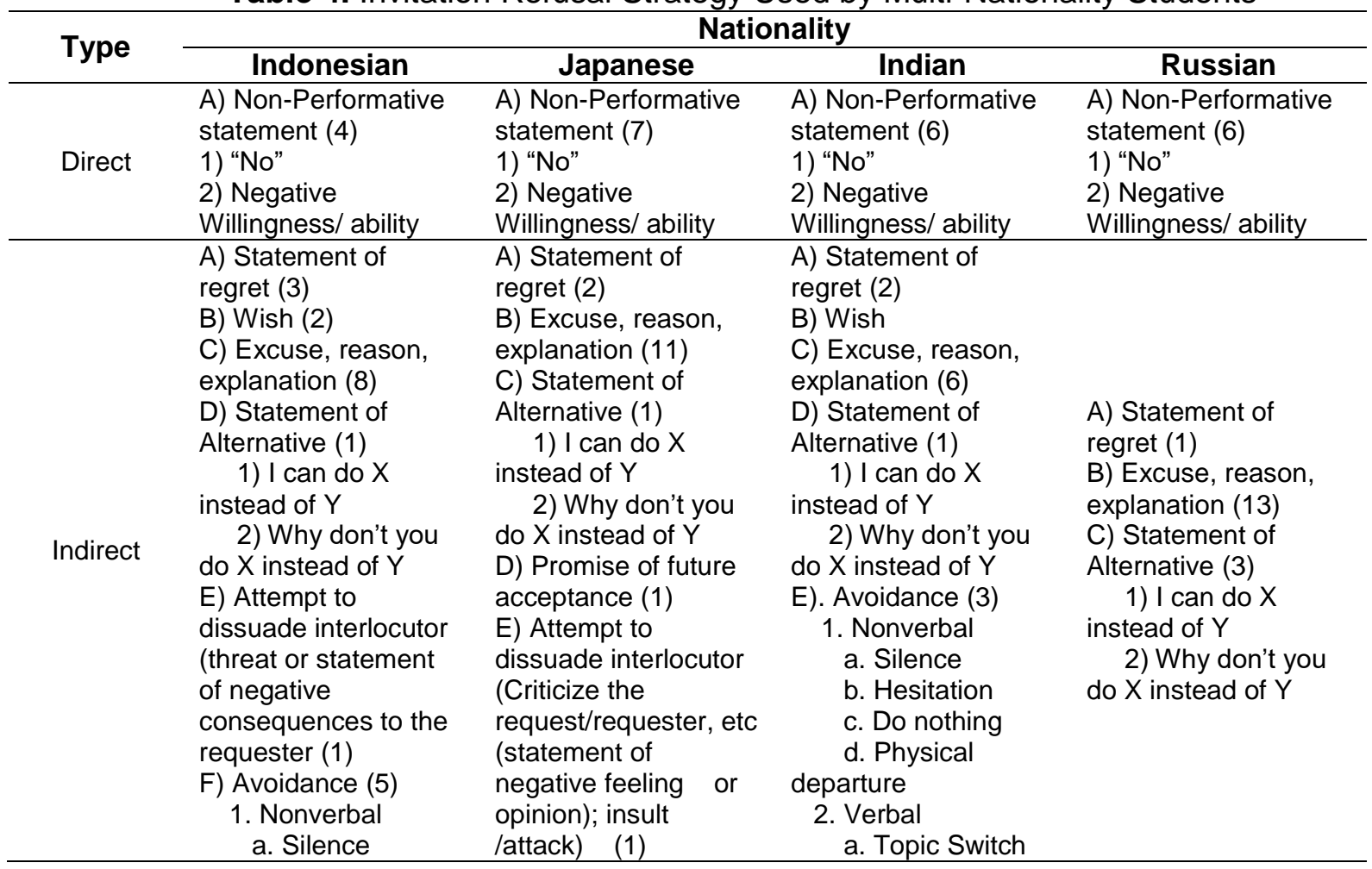




\begin{tabular}{|c|c|c|c|}
\hline & $\begin{array}{l}\text { b. Hesitation } \\
\text { c. Do nothing } \\
\text { d. Physical } \\
\text { departure } \\
\text { 2. Verbal } \\
\text { a. Topic Switch } \\
\text { b. Joke } \\
\text { c. repetition of } \\
\text { part of request, etc } \\
\text { d. Postponement } \\
\text { e. Hedging }\end{array}$ & $\begin{array}{l}\text { F) Avoidance (3) } \\
\text { 1. Nonverbal } \\
\text { a. Silence } \\
\text { b. Hesitation } \\
\text { c. Do nothing } \\
\text { d. Physical } \\
\text { departure } \\
\text { 2. Verbal } \\
\text { a. Topic Switch } \\
\text { b. Joke } \\
\text { c. repetition of } \\
\text { part of request, etc } \\
\text { d. Postponement } \\
\text { e. Hedging }\end{array}$ & $\begin{array}{l}\text { b. Joke } \\
\text { c. repetition of } \\
\text { part of request, etc } \\
\text { d. Postponement } \\
\text { e. Hedging }\end{array}$ \\
\hline $\begin{array}{l}\text { Adjuncts to } \\
\text { refusals }\end{array}$ & $\begin{array}{l}\text { 1.Statement of } \\
\text { positive } \\
\text { opinions/feeling or } \\
\text { agreement }\end{array}$ & 1. Pause filler (1) & 1. Pause filler (1) \\
\hline
\end{tabular}

Table 4 presents the refusal speeches performed by multi-nationality students in communication in context of invitation. The first one is the refusal speeches obtained from communication of Indonesian students consisting of 26 speeches. Among 26 refusal speeches, 4 of them were classified as direct (non-performative), 20 speeches were indirect and 2 speeches were adjunct to refusals. The result of analysis shows that not all indirect refusal strategies appeared in Indonesian communication. Among 20 indirect refusal speeches, 3 speeches were classified as statement of regret strategy, 2 speeches were classified as wish strategy, 8 refusal speeches were classified into excuse, reason, and explanation strategies, 1 speech was classified as statement of alternative, and 1 speech was attempt to dissuade interlocutor, and 5 speeches were classified as avoidance verbal hedging strategy. Among of adjunct refusal strategies, there were only two strategies appeared in Indonesians conversation, namely statement of positive opinions/ feeling or agreement. The second one is the refusal speeches obtained from communication of Japanese students consisting of 27 speeches by which the biggest number of refusal speeches were indirect refusal with the number of 19 speeches. It was classified into various indirect strategies such as, statement of regret (2 speeches), excuse, reason, and explanation (11 speeches), statement of alternative (1 speech), promise of future acceptance (1 speech), attempt to dissuade interlocutor: criticize the request (1 speech), verbal avoidance: hedging (3). While direct refusal appeared on 7 refusal speeches included into non-performative statement and all were categorized as negative willingness statement. The last type of refusal appeared on communication was adjunct to refusal. In terms of adjunct refusal type, only 1 pause filler appeared on the communication.

The next one is the refusal speeches obtained from communication of Indian students consisting of 18 speeches which were classified into two types of refusal strategies: direct and indirect refusal, 6 refusal speeches were categorized as direct refusal by which the strategy appeared were non-performative), while the rest 12 refusal speeches were classified as indirect refusal, there were excuse, reason, explanation (6), avoidance verbal: hedging (3), statements of regret (2), and attempt to dissuade interlocutor (1). The last one is the refusal speeches performed by the Russian students in context of invitation. Refusal speeches obtained from communication were 23 speeches which were classified into two types of refusal strategies: direct and indirect refusal, 6 refusal speeches were categorized as direct refusal by which the strategy appeared were non-performative, while the rest 17 refusal speeches were classified as indirect refusal by which the strategy appeared were statement of regret (1 speech), excuse, reason, explanation (13 speeches), and statement of alternative (3 speeches). 
Table 5. Suggestions Refusal Strategy Used by Multi-Nationality Students

\begin{tabular}{|c|c|c|c|c|}
\hline \multirow{2}{*}{ Type } & \multicolumn{4}{|c|}{ Nationality } \\
\hline & Indonesian & Japanese & Indian & Russian \\
\hline Direct & $\begin{array}{l}\text { A) Non-Performative } \\
\text { statement (3) } \\
\text { 1) "No" } \\
\text { 2) Negative } \\
\text { Willingness/ ability }\end{array}$ & $\begin{array}{l}\text { A) Non-Performative } \\
\text { statement (2) } \\
\text { 1) "No" } \\
\text { 2) Negative } \\
\text { Willingness/ ability }\end{array}$ & $\begin{array}{l}\text { A) Non-Performative } \\
\text { statement (6) } \\
\text { 1) "No" } \\
\text { 2) Negative } \\
\text { Willingness/ ability }\end{array}$ & $\begin{array}{l}\text { A) Non-Performative } \\
\text { statement (9) } \\
\text { 1) "No" } \\
\text { 2) Negative } \\
\text { Willingness/ ability }\end{array}$ \\
\hline Indirect & $\begin{array}{l}\text { A) Excuse, reason, } \\
\text { explanation (5) } \\
\text { B) Statement of } \\
\text { Alternative (4) } \\
\text { 1) I can do X } \\
\text { instead of Y } \\
\text { 2) Why don't you } \\
\text { do X instead of Y } \\
\text { C) Promise of future } \\
\text { acceptance (1) } \\
\text { D) Attempt to } \\
\text { dissuade interlocutor } \\
\text { (8) } \\
\text { 1. threat or } \\
\text { statement of negative } \\
\text { consequences to the } \\
\text { requester } \\
\text { 2. Criticize the } \\
\text { request/requester, etc } \\
\text { (statement of } \\
\text { negative feeling or } \\
\text { opinion); insult /attack } \\
\text { 3. Let interlocutor } \\
\text { off the hook } \\
4 \text {. Self- defense }\end{array}$ & 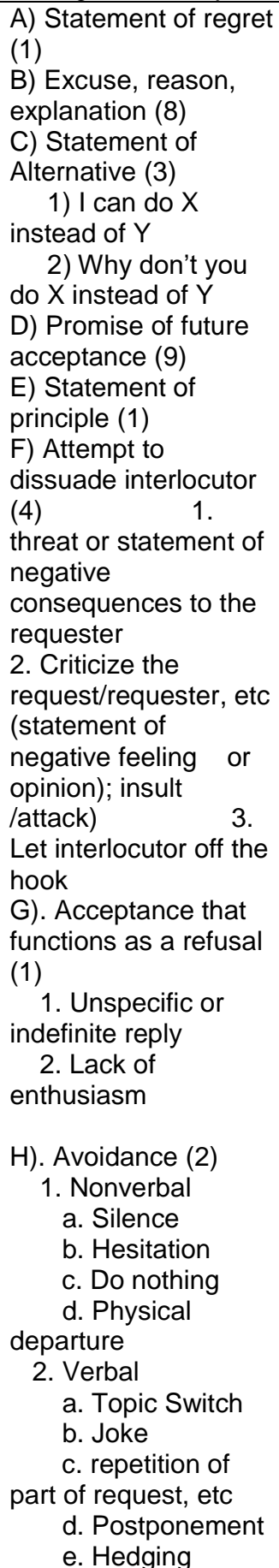 & $\begin{array}{l}\text { A) Excuse, reason, } \\
\text { explanation (8) } \\
\text { B) Statement of } \\
\text { Alternative (2) } \\
\text { 1) I can do X } \\
\text { instead of Y } \\
\text { 2) Why don't you } \\
\text { do X instead of Y } \\
\text { C) Promise of future } \\
\text { acceptance (1) } \\
\text { D) Attempt to } \\
\text { dissuade interlocutor ( } \\
\text { Criticize the } \\
\text { request/requester, etc } \\
\text { (statement of } \\
\text { negative feeling or } \\
\text { opinion); insult } \\
\text { /attack) (1) } \\
\text { E. Avoidance (1) } \\
\text { 1. Nonverbal } \\
\text { a. Silence } \\
\text { b. Hesitation } \\
\text { c. Do nothing } \\
\text { d. Physical } \\
\text { departure } \\
\text { 2. Verbal } \\
\text { a. Topic Switch } \\
\text { b. Joke } \\
\text { c. repetition of } \\
\text { part of request, etc } \\
\text { d. Postponement } \\
\text { e. Hedging }\end{array}$ & $\begin{array}{l}\text { A) Excuse, reason, } \\
\text { explanation (6) } \\
\text { B) Statement of } \\
\text { Alternative (2) } \\
\text { 1) I can do X } \\
\text { instead of Y } \\
\text { 2) Why don't you } \\
\text { do X instead of Y } \\
\text { C) Set condition for } \\
\text { future or past } \\
\text { acceptance (1) } \\
\text { C) Promise of future } \\
\text { acceptance (1) } \\
\text { D) Attempt to } \\
\text { dissuade interlocutor } \\
\text { (Self- defense) (1) }\end{array}$ \\
\hline $\begin{array}{l}\text { Adjuncts to } \\
\text { refusals }\end{array}$ & 1. Pause filler (1) & Pause filler (2) & & \\
\hline
\end{tabular}

Table 5 presents refusal speeches performed by multi-nationality students in context of suggestion. The first one is the refusal speeches obtained from Indonesian students consisting of 22 speeches which were classified into three types of refusal strategies: direct 
refusal, indirect refusal, and adjunct to refusal. 3 refusal speeches were categorized as direct refusal by which the strategy appeared were non-performative, while the indirect refusal by which the strategy appeared were excuse, reason, explanation (5), statement of alternative (4), promise future acceptance (1 speech), and attempt to dissuade interlocutor (8). Further, pause filler also appeared as adjunct to refusal strategy used in Indonesian conversation.

The next one is the Japanese refusal speeches in context of suggestion. Refusal speeches obtained from Japanese were 33 speeches which were classified into three types of refusal strategies: direct, indirect, and adjunct to refusal. Among 33 refusal speeches, 2 refusal speeches were categorized as direct refusal. The rest 29 refusal speeches were classified as indirect refusal by which the strategy appeared were statement of regret (1), excuse, reason, explanation (8), statement of alternative (3), promise future acceptance (9), statement of principle (1), attempt to dissuade interlocutor (4), and adjuncts (2). Furthermore, refusal speeches obtained from Indian were 20 speeches which were classified into two major types of refusal strategies: direct and indirect refusal. Among 20 refusal speeches, 6 refusal speeches were categorized as direct refusal by which the strategy appeared were non-performative. The rest 14 refusal speeches were classified as indirect refusal by which the strategy appeared were excuse, reason, explanation (8), statement of alternative (2), promise future acceptance (1), attempt to dissuade interlocutor (1), and avoidance (1). The last one is the refusal speeches obtained from Russian consisting of 20 speeches and included into two major types of refusal strategy: direct and indirect refusal. The result shows that there was no adjunct to refusal appeared in communication. Among 20 refusal speeches, 9 refusal speeches were categorized as direct refusal by which the strategy appeared were non-performative. The rest 11 refusal speeches were classified as indirect refusal by which the strategy appeared are excuse, reason, explanation (6), statement of alternative (2), promise future acceptance (1), set condition for future acceptance (1), attempt to dissuade interlocutor (1).

Concerning the result of the study presented previously, it is proven that Indonesian students generally utilized indirect refusal as the action of disengaging in interlocutors' desire. This finding confirms Herman et al.'s research finding (2013) that Indonesian EFL learners tended to use indirect strategies - the ones commonly used by Indonesian native speakers in refusing an invitation, suggestions, offers and requests. Moreover, Amarien, Kartomiharjo and Aziz (in Chojimah, 2015) pointed out that indirect manner in refusing was preferred by most Indonesian students. This result was evidently proven by previous research conducted by Chojimah (2015). Furthermore, Aziz (in Mulyani, 2013) pointed out that Indonesian tended to use obscure (not clear) strategy accompanied by various softener expressions and apologies for not being able to accomplish their interlocutor's request. In accordance with this, the indirect refusals were expressed by Indonesian students through statement of regret like 'sorry' which was also called as expression of apology. Similarly, it was found that Japanese students were prevalent to utilize indirect refusal. In Japanese culture, the norm seemed to avoid saying 'No' altogether (in particular, to refuse an offer or a request, to express disagreement and so on (Illiadi \& Larina, 2017). Avoiding saying "No" indicated that Japanese culture suggested to refuse a statement in indirect or implicit way. Congeniality between this general research finding with theory proposed by Illiadi and Larina (2017) emphasized that the role of Japanese culture had a great effect to the way how refusals were performed. In this study, the indirect refusal was generally expressed by Japanese students through reason and statement of alternative. It aligns with the study conducted by Al-Kahtani, (2005) that Saudis and Japanese used more explanation and give more excuses.

In contrast, Russian students generally preferred to utilize direct refusal. This analysis was evidently proven by a research conducted by lliadi and Larina (2017) investigating British and Russian refusal strategies from different perspective of crosscultural communication. It was found that the Russians used more direct strategies than the British and more taciturn and laconic. As Russian people due to their culture were more available and contactable, they preferred sincerity to tact and could afford to be more direct 
and straight forward (Illiardi \& Larina, 2017). However, being direct which is based on some theories potentially brings greater chance to offend or threat the hearer (interlocutor), did not happen in this context. Reflecting on Russian culture which is preferable to express refusal straightforward, this implies the performance of direct refusals by Russian students did not belong to the intention of offending or threating but referred to its common way when coping with refusals. Furthermore, the direct refusal strategies were mostly performed through nonperformative statement by which this direct refusal was negotiated through the expression of reason and attempt to dissuade interlocutor. It implies that Russian students attempted to clarify or negotiate refusal they made hence any misunderstanding yielded from refusal could be avoided. In line with Russian, it was found that Indian students were also generally performed the act of direct refusal to respond speech acts of request, offer, suggestion and invitation. This direct refusal was mostly performed through non-performative statement by which it was negotiated through the expression of reason. Overall, refusals are complex speech acts that require not only long sequence of negotiation and cooperative achievement, but also face-saving maneuvers to accommodate the noncompliant nature of the act (Gass \& Houck, 1999, p.2).

\section{Conclusion and Suggestion}

This study concludes that there were three types of refusal strategies namely direct, indirect, and adjunct used by the primary level students of Gandhi Memorial Intercontinental School (GMIS) Bali in responding for request, offer, invitation, and suggestion. For direct refusal strategy, the students used non-performative statement in responding all types of those speech acts. Meanwhile, for the indirect refusal strategy, the students totally used eight sub categories, such as (1) statement of apology/regret, (2) wish, (3) excuse/ reason/ explanation, (4) statement of alternative, (5) set condition for future or past acceptance, (6) promise of future acceptance, (7) attempt to dissuade the interlocutor, and (8) avoidance for refusing request, offer, invitation, and suggestion. Finally, for adjunct refusal strategy, the students used all of the three types of statement namely (1) statement of positive opinion/feeling or agreement, (2) pause fillers, and (3) gratitude/appreciation.

By considering the findings of this study, the researcher proposes some suggestions. First, the teacher as the converser needs to give the model of speech acts to the students which are relevant for intercultural communication. Second, the students are expected to adjust their speeches reagarding their interlocutor's different socio cultural background. As well for further researchers, this research is expected to be a stepping stone to conduct related study by considering other variables.

\section{Acknowledgement}

The writers' gratitude goes to several parties. First and foremost, the rector and the director of post graduate proram of Ganesha University of Education who facilitated them to accomplish this research. Second, the school principal, supervisor, teachers, and students of GMIS Bali for giving permission to carry out this research.

\section{References}

Al-Eryani, A.A. (2007). Refusal strategies by Yemeni EFL learners. The Asian EFL Journal Quarterly, 9(2), 19-34.

Al -Issa , A. (2003). Sciocultural transfer in L2 speech behaviors: Evidence and motivating factors. International Journal of Intercultural Relations, 27,581-601.

Al-Kahtani, W. (2005). Refusals realizations in three different cultures: A speech act theoretically based cross-cultural study. Journal of King Saud University, 18, 35-57.

Al-Shboul, Y. A. \& Huwari, I.F. (2016). A comparative study of Jordanian Arabic and American English refusal strategies. British Journal of English Linguistics, 4(3), 50-62.

Atieh, F, \& Yasin, S.Y.A .(2011). A descriptive-comparative analysis of apology strategies:The case of Iranian EFL and Malaysian ESL University Students. Published by Canadian Center of Science and Education. 
Beebe, L.M., Takahashi, T. \& Uliss-Weltz, R. (1990)."Pragmatics transfer in ESL refusals". In R.Scarcella, R., Anderson, E., Krashen, S.D. (Eds.), On the development of communicative competence in a second language. Cambridge, MA: Newbury House Publishers.

Brown, P. \& Levinson, S.C. (1987). Politeness: Some universals in language usage (chapter 22). Cambridge: Cambridge university press. Retrieved on July 8, 2018 from https://www.google.co.id/

Chojimah, N. (2015). Refusal and politeness strategies in relation to social status: A case of face-threatening act among Indonesian University Students. Theory and Practice in Language Studies, 5(5), 906-918. Doi: http://dx.doi.org/10.17507/tpls.0505.04.

Farnia, M \& Wu, X. (2012). An intercultural communication study of Chinese and Malaysian university students' refusal to invitation. International journal of English linguistics, 2(1), 162-176. Doi:10.5539/ijel.v2n1p162.

Gass, S. \& Houck.N. (1999) Interlanguage refusals: A cross cultural study of JapaneseEnglish. New York: Mouton de Gruyter. Retrieved on May 10, 2018 from https://books.google.co.id/

Han, T. \& Tazegul, A. (2016). Realization of speech acts of refusal and pragmatic competence by Turkish EFL learners. The reading matrix: An international online journal, $16(1), 161-178$.

Hedayatnejad, F., \& Rahbar, B. (2014). The effect of gender on realization of refusal strategies in formal and informal situation among Iranian EFL learners. ELT VoicesInternational journal for teachers of English, 4 (6), 20-43.

Hedayatnejad, F., Maleki., \& Mehrizi, A. (2016). The effect of social status and gender on realization of refusal of suggestion among Iranian EFL Intermediate Learners. Journal of Language Teaching and Research, 7 (1),99-109. DOI: http://dx.doi.org/10.17507/jtr.0701.11.

Herman, Simanjuntak. T. \& Eviliana. (2013). Strategi tindak tutur penolakan oleh mahasiswa semester II Jurusan Bahasa Inggris Politeknik Negeri Sriwijaya Tahun Akademik 2011/2012. ILMIAH, 5(3), 1-70.

Illiadi, P. L. \& Larina, T.V. (2017). Refusal strategies in English and Russian. RUDN Journal of Language Studies, Semiotics and Semantics, 8 (3), 531-542.

$\mathrm{Li}, \mathrm{X}$. \& Sun, J. (2015). A pragmatic study on refusal strategies by Chinese college nursing majors. Cambridge journal of china studies, 10 (2), 67-85.

Miles, M.B. \& Huberman, A.M. (1994). Qualitative data analysis (2nd.). California: Sage Publications, Inc.

Morkus, N. (2014). Refusals in Egyptian Arabic and American English. Journal of Pragmatics, 70, 86-107.

Mulyani, E.R. (2013). Two types of realization of making refusal in Sundanese context: A case study. ELTIN Journal, 1 (1), 11-22. Doi: https://doi.org/10.22460/ej.v1i1p\%25p.52

Nadar, F.X., Wijana, I D. P., Poedjosoerdarmo, S., Djawanai, S. (2005). Penolakan dalam Bahasa Inggris dan Bahasa Indonesia. Humaniora, 17(2),126-224.

Nelson, G. , Al-Batal, M. \& El-Bakary, W. (2002) . Directness vs. indirectness: Egyptian Arabic and US English communication style. International Journal of Intercultural Relations ,26, 39-57.

Sadeghi, K \& Savojbolaghchilar, S. (2011). A comparative study of refusal strategies used by Iranians and Americans. International journal of academic research, 3(2), 601-606.

Sattar, A. Hibba. Q. A., Salasiah C. \& Suleiman, Raja Rosina (2013). A study on strategies used in Iraqi Arabic to refuse suggestion. International journal of language society and culture, 30, 81-95.

Spencer-Oatey, H. (2006). Intercultural Conversation. Journal of Pragmatics, 38(3), pp.434437.

Tuncer, H. (2016). Refusal strategies used by Turkish university instructors of English. Novitas-ROYAL (Research on Youth and Language), 10(1), 71-90.

Umale, J. (2011). Pragmatic failure in refusal strategies: British versus Omani interlocutors. Arab World English Journal, 2(1), 18-46. 
Wannaruck, A. (2008). Pragmatic transfer in Thai EFL Refusals. Sage Publications, 39 (3) 318-337. Doi: 1177/0033688208096844

Wardaugh, R. (2006). Introduction to Linguistics (5 ${ }^{\text {th }}$ ed.). McGraw Hill Book Company.

Wierzbicka, A. 1987. English speech acts verbs: A semiotic dictionary. London: Academic Press.

Wijayanto, A. (2013). The Emergence of the Javanese Sopan Santun (Politeness) on the Refusal Strategies Used by Javanese Learners of English. The Internet Journal Language Culture and Society. URL:http://aaref.com.au/en/publication/journal/. Accessed on June 29th, 2018.

Xiaoning, Z. (2017). Politeness strategies in requests and refusals. A Published Paper, 1-12. Retrieved on May, 20, 2018 from https://semanticsarchive.net/Archive/DYzYWRiN/ Request-Refuse.pdf

Yule, G. (1996). Pragmatics. New York: Oxford university Press 